\section{УДК: 613.953.1:616-053.32}

\section{Д.О.Добрянський}

Львівський національний медичний університет імені Данила Галицького (м.Львів, Україна)

\section{СТРАТЕГІЇ ХАРЧУВАННЯ, ЩО ЗАБЕЗПЕЧУЮТЬ ОПТИМАЛЬНИЙ ПОСТНАТАЛЬНИЙ ФІЗИЧНИЙ РОЗВИТОК ПЕРЕДЧАСНО НАРОДЖЕНИХ НЕМОВЛЯТ}

Ключові слова: харчування, постнатальний фізичний розвиток, передчасно народжені немовлята.

\begin{abstract}
Резюме. Здоровий ріст і розвиток дитини в перші 1000 днів життя має критичне значення не лише для виживання $і$ покращення показників здоров'я в ранньому дитинстві, але й для профілактики важливих неінфекиійних захворювань старшого віку. Оптимальний постнатальний фізичний розвиток недоношених дітей можна визначити як такий, що не пов'язаний з несприятливими наслідками в короткостроковій i довгостроковій перспективі. Водночас, затримка розвитку вірогідно пов'язана з неадекватним харчуванням і віддаленими негативними неврологічними наслідками. Отже, належне харчування має забезпечувати досягнення оптимальних показників фізичного розвитку завдяки підтримиі постійного необхідного рівня споживання основних нутрієнтів й енергії. Повноцінне парентеральне харчування слід розпочинати відразу після народження глибоконедономеної дитини і продовжувати до моменту повного встановлення ентерального харчування. На тлі парентерального введення нутрієнтів так само від народження потрібно призначати мінімальне ентеральне харчування, яке стимулює дозрівання незрілого шлунково-кишкового тракту передчасно народженої дитини. Грудне молоко є найкращим продуктом мінімального харчування, оскільки воно є ефективнішим і безпечнішим, ніж альтернативні засоби. Як джерело поживних речовин, грудне молоко, однак, не забезпечує підвищених потреб глибоконедоношеної дитини, що визначає необхідність його збагачення, а також використання інших спеціальних продуктів харчування протягом першого року життя дитини. Щоби забезпечити оптимальні показники постнатального фізичного розвитку глибоконедоношених немовлят і відповідно покращити їх віддалений неврологічний прогноз, потрібна комплексна стратегія харчування $і$ моніторингу розвитку протягом перших років їх життя за участі неонатологів, педіатрів $і$ лікарів сімейної практики.
\end{abstract}

\footnotetext{
Результати численних сучасних досліджень підкреслюють критичне значення здорового росту і розвитку дитини в перші 1000 днів життя (9 місяців в утробі матері і перші 2 роки після народження) не лише для виживання і покращення показників здоров'я в ранньому дитинстві, але і для профілактики таких важливих неінфекційних захворювань дорослого віку, як ожиріння, цукровий діабет 2 типу, артеріальна гіпертензія, хвороби серця тощо. Доведено, що нормальні внутрішньоутробний і ранній постнатальний ріст і розвиток також мають надзвичайно важливе значення для повноцінного формування мозку дитини, що $€$ головною підставою для оптимізації харчування в цей критичний період. Харчовий дефіцит під час вагітності i/або в ранньому дитинстві значно збільшує ймовірність виникнення таких серйозних інфекційних захворювань, як пневмонія i діарея, які спричинюють майже третину всіх випадків смерті протягом перших 5 років життя. Щороку в результаті різних форм недоїдання у світі помирають майже 2,6 млн. дітей віком до 5
}

років, а ще більша кількість страждає від різних хвороб та неповносправності. Водночас спостерігається стрімке збільшення частоти діабету, ожиріння і серцево-судинних захворювань, що також пов'язують з особливостями харчування і фізичного розвитку протягом перших 1000 днів життя. Особливо вразливими до наслідків неадекватного харчування в ранньому дитинстві є діти з малою масою, насамперед, - передчасно народжені немовлята. Поєднання коротко- і довгострокових наслідків порушення росту і розвитку у цей період має також важливе соціально-економічне значення, істотно впливаючи на зростання вартості медичних послуг і сповільнюючи темпи економічного зростання суспільства.

Відомо, що певні події і впливи в ранньому житті людини здатні «програмувати» віддалені показники їі здоров'я. Біологічне програмування визначають як процес, в якому клітини розвиваються, функціонують й адаптуються до навколишнього середовища у відповідь на реалізацію природженого набору «команд», закодованих у 
хроматині. Значні нефізіологічні події або впливи на початку життя людини здатні змінювати ці програми, ймовірно з адаптивною метою, щоби забезпечити раннє виживання, проте, ціною виникнення хвороби в пізнішому віці. Саме тому перші 1000 днів життя немовляти є важливим періодом 3 унікальними можливостями для оптимізації стану здоров'я і харчування. Належні харчування і турбота про здоров'я матері і дитини в цей час тісно пов'язані 3 нормальним фізичним і психомоторним розвитком, формуванням навчального потенціалу дитини і довгостроковими показниками іii здоров'я. Немовля $з$ порушеним розвитком мозку має високий ризик віддалених когнітивних розладів, що призводить до поганої успішності в школі, отримання неповної або незакінченої освіти, а в подальшому відповідно - до низькооплачуваної праці, що ініціює хибне коло збереження харчового дефіциту і злиднів у наступних поколіннях. Отже, якщо ми хочемо вплинути на швидке поширення епідемії неінфекційних захворювань, розуміння механізмів «харчового програмування» обмінних процесів у цей період за участі епігенетичних й інших чинників, а також опрацювання інноваційних підходів до можливої корекції $є$ критичними. Такі заходи безпосередньо в неонатальному періоді і протягом перших 2 років життя мають спрямовуватись на забезпечення оптимального росту, сприятливого когнітивного розвитку, зниження показників смертності і захворюваності немовлят, а також зменшення тягаря неінфекційних захворювань у дорослому житті.

Питанням здорового харчування в перші 1000 днів людського життя останніми роками приділяється значна увага і в Україні. Зокрема, національні асоціації неонатологів і дитячих гастроентерологів розробили програми впровадження відповідних принципів, опрацювали теоретичні обгрунтування, клінічні протоколи (зокрема, уніфікований клінічний протокол «Ентеральне харчування недоношених немовлят») і методичні рекомендації.

Темпи росту людини є найвищими в останній триместр вагітності і в перші місяці життя. Під час останнього триместру вагітності маса дитини збільшується приблизно від 900 до 3400 г, тобто, більше, ніж утричі. В перші 4 міс. життя доношена дитина подвоює свою масу при народженні, а протягом найближчих 24 місяців її розміри збільшуються удвічі, проте, дорослих розмірів вона досягає лише в пізньому підлітковому віці. Водночас, мозок дитини набуває величини мозку дорослої людини (приблизно 1200 г) вже у 2 роки. В останньому триместрі вагітності маса мозку збільшується приблизно від 150 до 400 г, а до шестимісячного віку мозок знову подвоює свої розміри, досягаючи приблизно двох третин величини мозку дорослої людини. Склад і структура мозку також швидко змінюються протягом цього часу, і ці зміни продовжують відбуватися в ранньому дитинстві.

Відповідно перинатальний період характеризується високими потребами в енергії і нутрієн- тах, насамперед, білках, щоб підтримати необхідні темпи росту. Тому не дивно, що будь-який процес, що перериває концентрований потік поживних речовин до плода, наприклад, передчасні пологи, недостатнє харчування або плацентарна недостатність, призведе до народження дитини 3 малою масою тіла. Мозок видається особливо вразливим до харчового дефіциту у цей період, оскільки в маловагових дітей, порівняно 3 немовлятами з нормальною масою при народженні, частіше виявляють гірший неврологічний і розумовий розвиток. Недоношені діти особливо схильні до виникнення довгострокових пізнавальних і навчальних проблем прямо пропорційно ступеню їх незрілості. Так, найменші немовлята демонструють середній коефіцієнт інтелекту (IQ) на 0,8-1,5 стандартних відхилень (SD) менше, ніж у доношених ровесників. Останні дані також свідчать про навіть значнішу затримку неврологічного i розумового розвитку недоношених дітей, які народилися замалими для терміну гестації, порівняно 3 передчасно народженими немовлятами 3 нормальними показниками внутрішньоутробного росту. Порівняно $з$ дітьми 3 нормальною масою при народженні доношені немовлята із затримкою внутрішньоутробного розвитку характеризуються удвічі вищим ризиком дефіциту IQ.

Сучасні стратегії оптимізації неврологічних результатів виходжування дітей 3 малою масою при народженні найвищого ризику обов'язково передбачають зміну й вдосконалення практики харчування не лише безпосередньо в постнатальний період, але і в пізнішому віці.

Забезпечення харчових потреб хворих новонароджених ніколи не було легким завданням. Якщо потрібно вибирати між оптимізацією функціонування дихальної і серцево-судинної систем або оптимізацією харчування, як правило рішення приймається на користь першої опції. Результатом $є$ харчовий дефіцит, величина якого зростає в перші тижні життя, і який часто буває важко подолати наступними тижнями (рис. 1).

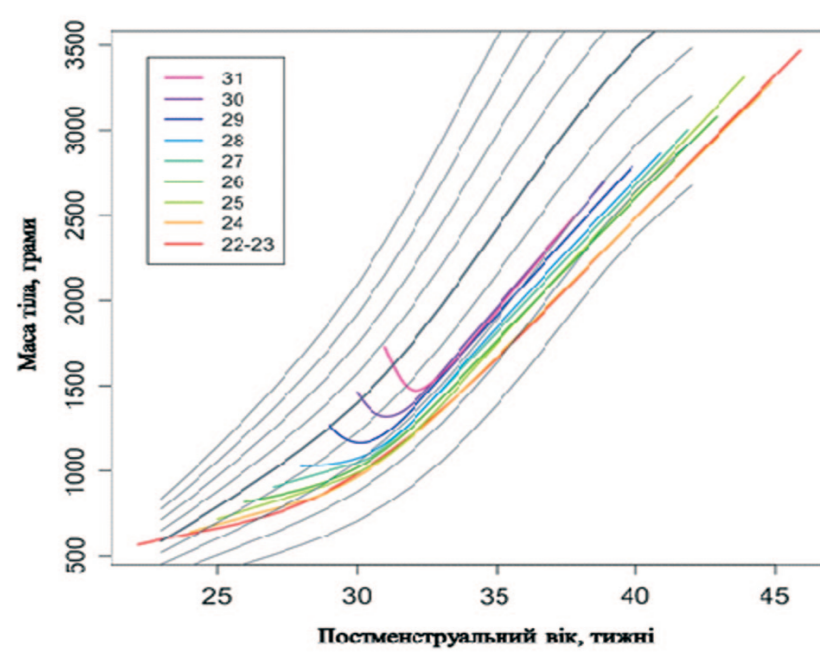

Рис.1. Середні криві збільшення маси залежно від гестаційного і постменструального віку немовлят, накладені на стандартні криві внутрішньоутробного росту за даними популяційного дослідження у Великій Британії (2014) 
Найважливішим наслідком такого дефіциту $€$ затримка постнатального фізичного розвитку, формування якої корелює з відділеними негативними неврологічними наслідками.

Грудне молоко є оптимальним продуктом харчування, але часто недоступно, особливо, в перші дні життя. Знижена моторика кишечника, гастроезофагальний рефлюкс і недостатність травної функції додатково утруднюють початок ентерального харчування (EX). Причини затримки постнатального фізичного розвитку недоношених дітей можуть бути різними, однак, більшість випадків пов'язуються 3 недостатнім харчуванням. Існує також хиткий баланс між оптимізацією харчового забезпечення і підвищенням ризику ускладнень, таких як перевантаження рідиною, некротичний ентероколіт (НЕК), ушкодження печінки тощо. Результатом є неприйнятний рівень відмінностей у клінічній практиці різних установ і тих їі peзультатах, які пов'язані з постнатальним фізичним розвитком і харчуванням.

Незважаючи на численні переваги грудного молока, воно все ще недостатньо використовується. Не завжди зрозуміло, чому саме так відбувається; часто посилаються на соціально-економічний статус і відсутність мотивації у матерів, проте у більшості відділень інтенсивної терапії новонароджених фіксуються подібні і недостатні показники частоти грудного вигодовування. Численні дослідження показали, що порівняно із сумішами грудне молоко краще переноситься, а годування ним знижує ризик НЕК. Існують також імунологічні переваги, які реалізуються у менший ризик виникнення інфекційних захворювань й імунних порушень в подальшому житті.

Важливим $є$ питання переваг раннього і швидкого порівняно з відстроченим і повільним призначенням і збільшенням об'єму ЕХ. Результати досліджень свідчать, що ранній початок і регульоване швидке збільшення об'єму ЕХ пов'язані 3 кращими толерантністю і показниками фізичного розвитку глибоконедоношених немовлят. Тим не менше, у клінічній практиці не завжди враховується, що протягом вагітності плід активно ковтає велику кількість амніотичної рідини, а тому народжується до певної міри адаптований до ЕX. Водночас пізній початок ЕХ може призводити до ускладнень, пов'язаних з повним парентеральним харчуванням, повільнішого досягнення повного добового об'єму харчування і відповідно - нижчих темпів постнатального росту. Призначення дитині з дуже малою масою тіла при народженні EX у зростаючому об'ємі в перші 4 дні життя i збільшення добового об'єму харчування на 20-30 мл/кг/добу не збільшують ризику НЕК [20].

С чимало інших питань, які потребують широкого обговорення і досягнення консенсусу щодо клінічної практики, особливо, за відсутності науково обгрунтованих рекомендацій. Однак, незаперечним $є$ те, що сучасні теорія і практика неонатального харчування змістили акценти від простих показників виживання і росту маловагових немовлят на оптимізацію впливу кожного мікро- і макронутрієнту на їх довгостроковий розвиток і профілактику захворювань.

Чому оптимальний постнатальний фізичний розвиток є важливим?

Затримці постнатального фізичного розвитку (ЗПФР) недоношених дітей почали приділяти серйозну увагу лише наприкінці 1990-х років. Уже в той час стало зрозуміло, що ця проблема пов'язана переважно 3 неадекватним споживанням харчових речовин, а відповідні зусилля i зміна клінічної практики виявились успішними у зменшенні $\dddot{11}$ поширення. Проте, незважаючи на всі зусилля, ЗПФР продовжує виявлятись у більшості глибоконедоношених немовлят і залишається важливим викликом у виходжуванні цієї категорії новонароджених. Важливість цієї проблеми насамперед визначається асоціацією 3 негативними віддаленими неврологічними наслідками. Одне з найбільш масштабних і найважливіших досліджень Ehrenkranz та співавт. у 2006 p. засвідчило залежність важкості неврологічного дефіциту від ступеня ЗПФР. Асоціацію між ЗПФР i несприятливими віддаленими неврологічними показниками незалежно підтвердили й інші автори, не залишаючи жодних сумнівів щодо шкідливого впливу ЗПФР на віддалений неврологічний розвиток маловагових дітей. Було також встановлено, що ЗПФР підвищує ризик виникнення ретинопатії недоношених.

Використання спеціальних продуктів харчування, зокрема, збагаченого грудного молока i спеціальних молочних сумішей забезпечило покращення показників постнатального фізичного розвитку у найменших немовлят на момент досягнення постменструального віку (ПМВ) 36 тиж. i/або виписки $з$ лікарні. Відповідно ближчий до нормального фізичний розвиток був пов'язаний 3 кращими віддаленими неврологічними результатами. Водночас, на момент досягнення ПМВ 36-40 тиж. структура тіла у недоношених дітей характеризується низькою часткою «пісної» маси і відносно більшою кількістю жиру (особливо в абдомінальній ділянці) порівняно з плодом такого ж ПМВ, який нормально ріс і розвивався. Крім того, у недоношених дітей 3 дуже малою масою при народженні виявляється значна затримка лінійного росту, яка зберігається принаймні 2 роки після виписки зі стаціонару і спричинює менші розміри таких дітей навіть в підлітковому і дорослому віці. Основною причиною такої тривалої затримки росту $€$ неадекватне харчування, особливо в перші 2-4 тиж. життя, коли фізіологічна нестабільність не дозволяє забезпечити належне споживання білка й енергії. Навіть за умови використання сучасних підходів до раннього харчування таких немовлят, дефіцит білка й енергії все ж накопичуються протягом перебування дитини в лікарні. Крім того, критично важливим є забезпечення оптимального співвідношення білок/енер- 
гія, від якого залежить формування нормальної структура тіла недоношеної дитини. Якщо вміст енергії у збагаченому молоці (суміші) є надлишковим щодо білка, постнатальний ріст буде супроводжуватись надмірним відкладенням жиру за рахунок «пісних» тканин. 3 іншого боку, якщо білок в надлишку по відношенню до енергії, надлишок білка може буде використовуватись для продукції енергії, а не для потреб росту.

Вимірювання маси і довжини тіла, а також окружності голови є основою моніторингу фізичного розвитку недоношених немовлят у відділеннях інтенсивної терапії новонароджених. Ці показники використовуються для оцінки росту i розвитку всіх органів тіла, включаючи головний мозок. Вони також позитивно корелюють з віддаленими неврологічними наслідками.

Прості вимірювання маси, довжини і окружності голови, однак, скоріше за все, не виявляють специфічного дефіциту «пісної» маси тіла, а також порушення структури органів і тканин, пов'язаних 3 недостатнім споживанням білка. Ріст і диференціація нейронів порушені в умовах нестачі білка. Доведено, що внутрішньоутробний дефіцит нутрієнтів в експериментальних фетальних моделях гальмував ріст і розвиток майже всіх систем і органів, включаючи легені, серце, нирки, печінку, підшлункову залозу, і скелетні м'язи. Збільшення «пісної» маси тіла також насамперед залежить від рівня споживання білка. Амінокислоти не лише використовуються в якості «будівельного матеріалу» для формування нових тканин, а й істотно впливають на регуляцію синтезу м'язового білка і секрецію фактора росту.

Оскільки на сьогодні отримано серйозні докази того, що ЗПФР, головним чином, якщо не повністю, є наслідком неадекватного харчування, зусилля, спрямовані на профілактику цієї проблеми, були зосереджені на оптимізації парентерального й ентерального харчування. Чимало штучних перешкод на цьому шляху успішно подолано, проте реальне забезпечення відповідних харчових потреб екстремально недоношеної дитини все ще залишається недосяжною метою.

Які показники постнатального фізичного розвитку вважати оптимальними?

Хоча значну ЗПФР легко визначити, ідентифікація більш помірного дефіциту фізичного розвитку може бути непростим завданням. Однак, із практичної точки зору завжди важливо діагностувати наявну ЗПФР, оскільки саме для цієї категорії немовлят показані специфічні втручання. В ідеалі адекватний фізичний розвиток можна визначити як такий, що не пов'язаний з будь-якими короткостроковими або довгостроковими несприятливими наслідками. На жаль, ми не маємо даних, щоб описати належний фізичний розвиток за цим визначенням. Практично можливо визначити належний постнатальний фізичний розвиток за іншою ознакою, а саме, - відповідністю темпам внутрішньоутробного розвитку плода. Зрештою, плід, який нормально росте і розвивається, традиційно використовується як модель для оцінки потреб в поживних речовинах на різних етапах свого росту і розвитку. Нормальний внутрішньоутробний розвиток достатньо вивчений і його параметри відображено на кількох стандартних кривих росту. Однак, наскільки близько до відповідних параметрів фізичного розвитку плода мають знаходитись показники недоношених немовлят, щоб уважатися «належними»? Перехід від фетального до позаутробного життя передбачає зменшення позаклітинного об'єму рідини, що, як уважається, $\epsilon$ незворотним. Якщо припустити, що кількість позаклітинної рідини, яка складає близько 50 \% від маси тіла, зменшується на $10 \%$, втрату $5 \%$ маси можна вважати фізіологічною, оскільки іiі можна пояснити виключно втратами води. Відповідно до цієї точки зору, належний фізичний розвиток можна визначити як динаміку маси тіла, траєкторія якої $є$ паралельною нормальній кривій збільшення маси плода, однак, знаходиться приблизно на 5\% нижче останньої. Відповідно належною буде вважатись маса дитини, яка дорівнює або перевищує 95\% очікуваної маси плода. Хоча цілком імовірно, що незначна ЗПФР (дефіцит маси незначно більше, ніж 5\%) є нешкідливим, наявні дані, на жаль, не дозволяють визначити будь-які межі затримки росту без потенційно шкідливих наслідків. Таким чином, потрібно прагнути уникнути будь-якої ЗПФР.

Що спричинює затримку постнатального фізичного розвитку (ЗПФР)?

Висновки стосовно причин недостатнього постнатального фізичного розвитку грунтуються на результатах обсерваційних досліджень, оскільки інші дані відсутні. Неадекватне споживання нутрієнтів й енергії є основною, якщо не єдиною, причиною цього ускладнення, хоча не можна виключити повністю ймовірність того, що інші нехарчові чинники можуть відігравати певну роль в етіології ЗПФР. Зокрема, в одному з проспективних досліджень із залученням 148 екстремально недоношених немовлят було встановлено, що вищий рівень споживання білків й енергії в перший тиждень життя асоціюється 3 кращими показниками ментального розвитку у віці 18 міс. Цей висновок $є$ вагомим аргументом на користь оптимізації практики харчування таких немовлят відразу після народження.

Який рівень споживання нутрієнтів й енергії можна вважати адекватним?

Встановлено, що ранній постнатальний фізичний розвиток найбільше залежить від рівня споживання білків й енергії. Щоб підтримати відповідні гестаційному віку темпи засвоєння білка глибоконедоношені діти потребують більшої його кількості, ніж може забезпечити споживання грудного молока або стандартних сумішей для немовлят. Відповідно до сучасних рекомендацій, щоб забезпечити внутрішньоутробні темпи росту, немовлятам масою $<1000$ г потрібно споживати 4,0-4,5 г/кг на добу білка, а дітям масою 1000- 
1800 г - 3,5-4,0 г білка/кг/добу. Потреби на парентеральному харчуванні є меншими приблизно на $10 \%$. Рекомендоване споживання енергії за умови ентерального харчування становить 110-135 ккал/ кг на добу, а на повному парентеральному - мінімум 80 ккал/кг/добу. Рівень забезпечення всіма іншими поживними речовинами також має відповідати потребам.

3 іншого боку на пізніх термінах вагітності темпи синтезу білка і відповідно росту у плода знижуються, що зменшує потребу в білках. Приблизно в 36 тиж. вагітності ці показники досягають показників здорової доношеної дитини, потреби якої в білках коливаються в діапазоні від 1,5 до 2,0 г/кг/добу. Проте, у період між 34 і 40 тиж. вагітності мозок дитини продовжує інтенсивно розвиватися, включаючи збільшення на 50 \% об'єму кори. Дефіцит білків може порушувати ці процеси. Крім того, ріст і розвиток мозку у недоношеної дитини 3 гестаційним віком $>34$ тиж. особливо вразливі, якщо є загальна затримка фізичного розвитку в результаті хвороби. Таким чином, щоби забезпечити відповідний гестаційному віку фракційний синтез білка і належні темпи фізичного розвитку, такій недоношеній дитині потрібно споживати більше 2 г/кг/добу білка.

Чому споживання харчових речовин й енергії часто неадекватне?

Історично склалося так, що неадекватність парентерального й ентерального харчування пояснювали міркуваннями «безпеки» пацієнта. Парентеральне харчування в перші дні життя тривалий час уважали занадто ризикованим, і тому призначали пізно й обережно. Особливо це стосувалось жирових емульсій. Такий підхід роками залишався незмінним, поки дослідження не почали демонструвати безпеку раннього парентерального харчування у недоношених дітей. Результати ключових досліджень, які довели повну безпеку й ефективність парентерального харчування, розпочатого протягом години після народження з'явились лише у 2004-2005 рр.. Сьогодні звичним стало призначення повного або майже повного парентерального харчування в перші години після народження без будь-яких серйозних побічних ефектів.

3 раннім початком EX також пов'язували певні ризики, насамперед, виникнення некротичного ентероколіту, і тому стандартною практикою було відстрочення EX на дні і тижні. Ранне трофічне (мінімальне) харчування почали використовувати в середині 1990-х років, але збільшення об'єму харчування, як правило, було повільним. Сьогодні повна відміна годування все ще широко практикується, хоча і протягом коротших періодів часу, ніж в минулому. Крім того, у частини фахівців все ще зберігаються сумніви з приводу безпеки «високого» рівня споживання білка за відсутності будь-яких доказів на їх користь. Після з'ясування питань безпеки стали очевидними інші можливі причини неадекватного харчування. Існують помилкові уявлення про кількість білка, необхідну для забезпечення належних темпів росту, і про важливість реального забезпечення підвищених харчових потреб з перших хвилин позаутробного життя; використовуються неадекватні продукти харчування; приділяється недостатньо уваги систематичній оцінці фізичного розвитку немовлят. I, нарешті, існують об'єктивні причини недосягнення адекватного споживання харчових речовин. Мова йде не лише за формальну відсутність потрібних продуктів харчування (насамперед, парентерального) в сучасних вітчизняних умовах, але й за реальні можливості забезпечити підвищені потреби. Наприклад, мультикомпонентні збагачувачі грудного молока містять недостатньо білка і їх використання не завжди забезпечує його адекватне споживання.

Сучасна стратегія харчування глибоконедоношених дітей

У цілому стратегія запобігання затримці постнатального фізичного розвитку спрямована на забезпечення постійного належного споживання всіх нутрієнтів й енергії у всі періоди. Отже, темпів постнатального фізичного розвитку, які б відповідали внутрішньоутробним, можна очікувати лише тоді, коли харчове забезпечення дитини від моменту народження буде відповідати потребам. Клінічна практика вигодування недоношених немовлят формувалася роками, змінюючись з розвитком неонатології й отриманням нових даних.

Парентеральне харчування (ПЕХ). В перші дні життя всі глибоконедоношені діти залежать від ПЕХ, тому що незрілість їх шлунково-кишкового тракту виключає можливість споживання потрібної кількості харчових речовин і енергії ентеральним шляхом. Враховуючи встановлені безпеку й ефективність негайного ПЕХ [51,52], його слід розпочати відразу після народження 3 дозою амінокислот не менше 3 г/кг/добу. Протягом 24 год. після народження також потрібно призначити жирову емульсію в дозі не менше 1 г/кг/добу, швидко збільшуючи іiі наступними днями до 2-3 г/кг/ добу. За умови нормоглікемії важливо періодично збільшувати і швидкість інфузії глюкози.

Протягом наступних 1-3 тиж. ПЕХ, як правило, залишається домінуючим, або, принаймні значним джерелом поживних речовин і енергії для дитини. Водночас важливо якомога скоріше розпочати мінімальне ЕX, яке має поступово трансформуватись в повноцінне EX і замінити парентеральне. Останнє припиняють, якщо об'єм ЕX досягне 90 \% від потреби.

Мінімальне ентеральне харчування (MEX). Метою MEX є стимуляція незрілого травного каналу, щоб якомога скоріше забезпечити можливість його прийнятного функціонування. Стимуляція відбувається завдяки місцевій дії невеликої кількості харчового субстрату (оптимально, молозива або грудного молока). Незрілий кишечник характеризується зниженою моторикою, що клінічно виявляється наявністю залишку у шлунку [47]. Цю особливість не слід розглядати як про- 
типоказання до продовження MEX. MEX потрібно розпочати в день народження або наступного дня, оскільки більша затримка може призвести до атрофії кишечника. Нестабільність стану дитини не $є$ протипоказанням до МЕX. Існує недостатньо інформації, щоб рекомендувати, як саме проводити MEX, - зі сталим невеликим добовим об'ємом упродовж встановленої кількості днів або 3 постійним збільшенням об' єму харчування за умови зменшення залишку у шлунку (що можна вважати ознакою підвищення функціональної зрілості травного каналу). Вибір продукту для MEX має важливе значення. Перевагу слід надавати грудному молоку (молозиву), яке має важливі трофічні й імунно-захисні властивості. Грудне молоко краще i безпечніше стимулює дозрівання кишечника, ніж суміш. Проте, відсутність грудного молока не повинна затримувати початок MEX. У розвинених країнах в таких випадках використовують донорське грудне молоко, однак, прийнятним уважається і призначення суміші.

Ентеральне харчування (ЕX). Годування грудним молоком, яке $\epsilon$ пріоритетним продуктом харчування недоношеної дитини, не забезпечує споживання необхідної кількості білка і більшості інших харчових речовин в об'ємі, який толерується глибоконедоношеним немовлям, тобто $\leq$ 200 мл/кг на добу. Отже, молоко треба додатково збагачувати нутрієнтами. Збагачення, як правило, розпочинають після досягнення добового об'єму харчування 100 мл/кг на добу. Комерційні збагачувачі містять білок, вуглеводи і/або ліпіди (енергія), мінерали, особливо кальцій і фосфор, а також вітаміни. Додавання стандартної кількості збагачувача збільшує калорійність молока до 80 ккал/100 мл, а також підвищує вміст у ньому більшості поживних речовин до рівня, що забезпечує задоволення потреб росту. Збагачувачі суттєво не збільшують осмоляльність молока. Кількість білка, що міститься у більшості збагачувачів, не забезпечує потреби оптимального фізичного розвитку. Це визначає необхідність додаткового збагачення білком, що може здійснюватись кількома методами (регульоване і цільове збагачення) 3 доведеними ефективністю і безпекою.

Якщо можливість годування грудним молоком відсутня, слід використовувати молочні суміші, призначені для недоношених немовлят. Спеціальні суміші, які містять $\approx 3$ г білка /100 ккал звичайно задовольняють потреби дітей масою тіла 15001800 г. Сучасні суміші з концентрацією білка від 3,3 і 3,6 г/100 ккал («з високим вмістом білка») слід використовувати для дітей з масою тіла менше 1500 г. Оскільки склад грудного молока є індивідуальним, загалом, годування сумішами з більшою імовірністю забезпечує адекватне споживання білка, ніж годування збагаченим молоком.

Для немовлят, які народилися між 24 і 30 тижнями вагітності, після виписки зі стаціонару до досягнення скоригованого віку 6-9 міс. рекомендуються спеціальні виписні (збагачені) суміші, тому що більшість 3 цих дітей мають значний кумулятивний дефіцит білків навіть на момент досягнення ПМВ 40 тиж.

Порівняно зі стандартними адаптованими сумішами для немовлят, такі продукти харчування містять більше енергії, білка, мікронутрієнтів i вітамінів, а також біологічно активні речовини, споживання яких дозволяе забезпечити кращі темпи постнатального фізичного розвитку. Проте, виписні (збагачені) суміші мають меншу харчову «щільність», ніж спеціальні суміші для недоношених (маловагових) немовлят, що дозволяє уникнути надмірного споживання основних нутрієнтів й енергії. Виписні (збагачені) суміші переважно використовують в амбулаторних умовах, проте, за наявності показань (забезпечення індивідуальних харчових потреб, ЗПФР) їх можна призначати і в стаціонарі. Зокрема, якщо є потреба використати таку суміш після виписки дитини додому, доцільно розпочати її призначення в стаціонарі.

Було показано, що використання сумішей такого типу протягом 6 міс. після виписки, порівняно iз звичайними сумішами, у немовлят 3 дуже малою масою тіла забезпечувало збільшення частки пісної маси без збільшення відсотку жиру у віці 1 року і відповідно зменшення загального об'єму жирової тканини, жирових відкладень на тулубі, а також концентрації інсуліну натще у віці 2 років. Результати досліджень останніх років свідчать, що вигодовування збагаченими виписними сумішами $€$ важливим для здоров'я і розвитку недоношених немовлят, які перебувають на штучному харчуванні. Хоча використання збагачених сумішей після досягнення ПМВ 40 тиж. може не впливати на кількісні показники постнатального фізичного розвитку передчасно народжених немовлят, воно, однак, покращує «якість» формування нових тканин. Так, Picaud та співавт. продемонстрували кращі показники фізичного розвитку у віці 4 і 12 міс, а також мінералізації кісток в 4 міс. у немовлят 3 дуже малою масою при народженні, яких протягом 2 міс. після виписки зі стаціонару годували спеціальною сумішшю, порівняно з показниками дітей, які отримували стандартну адаптовану суміш. В іншому дослідженні у недоношених немовлят, яких годували виписними сумішами, у скоригованому віці 6 міс. була меншою питома кількість жирової тканини, ніж у дітей, які отримували стандартну адаптовану суміш або грудне молоко. Передчасно народжені немовлята, які після виписки споживали збагачені суміші, мали більшу загальну масу пісних тканин і периферичної жирової тканини і меншу - «центрально» локалізованої жирової тканини порівняно 3 дітьми, яких годували стандартними сумішами [58]. Ці дані свідчать про те, що годування виписними сумішами не стимулює утворення «центральної» жирової тканини, що асоціюється з розвитком метаболічного синдрому у старшому віці.

Отже, для досягнення оптимальних показників постнатального фізичного розвитку недоноше- 
них немовлят і відповідно - покращення неврологічних наслідків їх виходжування надзвичайно важливими $€$ розуміння, знання і систематична реалізація описаної єдиної стратегії харчування глибоконедоношених немовлят на всіх етапах надання їм медичної допомоги із залученням неонатологів, педіатрів і лікарів сімейної практики.

Приклад сучасної практики харчування глибоконедоношених дітей.

Парентеральне харчування (ПЕХ). Парентеральне харчування розпочинають якомога скоріше, але не пізніше 2 год. життя, за допомогою «початкового» розчину, який в об'ємі 60 мл/кг на добу забезпечує споживання 3 г/кг на добу амінокислот i 4 мг/кг/хв. глюкози. Протягом 24-36 год. початковий розчин замінюють повноцінним розчином для парентерального харчування. Уведення амінокислот підтримують на рівні 3,0-3,5 г/кг/добу, а швидкість інфузії глюкози щоденно збільшують на 1-2 мг/кг/хв.. за умови нормоглікемії. Внутрішньовенне введення жирової емульсії розпочинають протягом 24 год. від народження в дозі 1 г/кг/добу, збільшуючи їі наступними днями до 2-3 г/кг/добу. Цей режим використовується доки триває MEX. Із поступовим зменшенням об'єму парентерального харчування підтримується належне загальне забезпечення білками. Після зменшення об'єму ПЕХ нижче 60 мл/кг/ добу концентрація амінокислот у розчині залишається на рівні 5 г/100 мл, і їх споживання поступово зменшується зі зменшенням об'єму ПЕХ. Доза внутрішньовенних ліпідів підтримується на рівні, який дозволяє повністю забезпечити відповідні потреби, приблизно до 1 дня до припинення парентерального введення амінокислот. У цей момент доза ліпідів зменшується до 1 г/кг/добу або жирова емульсія відміняється взагалі. Як правило, уведення розчину ПЕХ, що містить амінокислоти і глюкозу, припиняють після досягнення 90\% об’єму ЕХ від потреби.

Мінімальне ентеральне харчування (MEX). MEX розпочинають грудним молоком на перший або другий день життя в об'ємі 1-2 мл спочатку кожні 8 год. За відсутності молока (молозива) використовують суміш для недоношених дітей. MEX продовжують, незважаючи на об'єм залишку у шлунку. MEX призупиняють, якщо залишок містить домішку жовчі або є підозра на обструкцію травного каналу. Зі зменшенням об'єму залишку спочатку поступово збільшують частоту годувань, а пізніше - об'єм.

Збагачення грудного молока. Збагачення розпочинають, коли добовий об'єм ЕХ досягає 25 мл/добу. Після досягнення об'єму 120-130 мл/кг/ добу або скоріше для збагачення 100 мл молока використовують 2 додаткових пакетика мультикомпонентного збагачувача, щоби збільшити рівень споживання білка. Одночасно також підвищується калорійність молока приблизно до 90 ккал/100 мл, а також збільшується вміст кальцію, фосфору і всіх інших нутрієнтів, що містяться у збагачувачі. Молоко, яким годують всіх немовлят масою < 1000 г, а також дітей масою 1000-1499 г, які демонструють ЗПФР, додатково збагачують білком. Це збільшує енергетичну цінність молока до 100 ккал на 100 мл і забезпечує споживання 3,5 г білка /100 ккал.

Фізичний розвиток. Бажані темпи збільшення маси становлять близько 15-20 г/кг на добу (наприклад, немовля масою 1000 г має збільшувати масу на 15-20 г на добу, а немовля масою 2000 г - 30-40 г/добу). Після досягнення скоригованого віку 36 тиж. цей показник зменшується до $\approx 10$ г/кг на добу. Для довжини тіла й обводу голови нормальні темпи росту відповідають середньому збільшенню на 0,9 см за тиждень Динаміку маси, довжини тіла й обводу голови оцінюють щотижня і відображають відповідні показники на стандартних кривих $[42,43]$, що дозволяє візуально оцінити адекватність фізичного розвитку дитини.

Основними досягненнями неонатальної нутриціології останніх десятиліть стали можливість забезпечення раннього парентерального харчування, а також удосконалення технологій ентерального харчування 3 використанням нових спеціальних продуктів для недоношених дітей. Таким чином відбулась практична реалізація теоретичної концепції «харчування на початку життя», що вже забезпечило досягнення кращих результатів виходжування передчасно народжених немовлят. Водночас чимало проблем, пов'язаних 3 оптимальним харчовим забезпеченням цієї категорії немовлят найвищого перинатального ризику залишаються невирішеними. Основне наше завдання - постійно вдосконалювати клінічну практику, забезпечуючи реальне впровадження нових ефективних і безпечних методів і підходів, і за допомогою цього постійно покращувати кінцеві результати своєї роботи.

\section{Література}

1. Результати сучасного дослідження та обгрунтування прикладного меню на 7 днів для здорових дітей віком від 1 до 3 років: Метод рекомендації / О.Г. Шадрін, С.Л. Няньковський, Д.О.Добрянський [та ін.]. - К., 2013. - 24 с.

2.Dobbing J. Quantitative growth and development of human brain / J. Dobbing, J. Sands // Arch. Dis. Child. - 1973. - V.48. - P.757-767.

3. Georgieff M.K. Nutrition and the developing brain: nutrient priorities and measurement / M.K. Georgieff // Am. J. Clin. Nutr. 2007. - V.85. - P.614S-620S.

4. Rogers E.E. Neurodevelopmental outcomes of infants who experience intrauterine growth restriction/E.E. Rogers, R.E. Piecuch // NeoReviews. - 2009. - V.10. - P.e100-e112.

5. Cognitive function after intrauterine growth restriction and very preterm birth / E. Morsing, M. Esard, D. Ley [et al.] // Pediatrics. - 2011. - V.127. - P.e874-e882.

6. Neurologic outcomes at school age in very preterm infants born with severe or mild growth restriction / I. Guellec, A. Lapillonne, S. Renolleau [et al.] // Pediatrics. - 2011. - V.127. - P.e883-e891. 
7. Jelliffe-Pawlowski L.L. Neurodevelopmental outcome at 8 months and 4 years among infants born full-term small-for gestational age / L.L. Jelliffe-Pawlowski, R.L. Hansen // J. Perinatol. - 2004. - V.24. - P.505-514.

8. Birth weight and longitudinal growth in infants born below 32 weeks' gestation: a UK population study / T.J. Cole, Y. Statnikov, S. Santhakumaran [et al.] // Arch Dis Child Fetal Neonatal Ed. - 2014. - V.99. - P.F34-F40.

9. Corpeleijin WE. Optimal growth of preterm infants / WE. Corpeleijin, SM. Kouwenhoven, JB. van Goudoever // World Rev. Nutr. Diet.- 2013.-V.106.-P.149-55.

10. Morgan J. Slow advancement of enteral feed volumes to prevent necrotizing enterocolitis in very low birth weight infants / J. Morgan, L. Young, W. McGuire // Cochrane Database Syst. Rev. - 2013. - N3. - CD001241.

11. Carlson S.J. Nutrient intakes and growth of very low birth weight infants / S.J. Carlson, E.E. Ziegler // J. Perinatol. - 1998. - V.18. - P.252-258.

12. Longitudinal growth of hospitalized very low birth weight infants / R.A. Ehrenkranz, N. Younes, J.A. Lemons [et al.] // Pediatrics. - 1999. - V.104. - P.280-289.

13. Clark R.H. Extrauterine growth restriction remains a serious problem in prematurely born neonates / R.H. Clark, P. Thomas, J. Peabody // Pediatrics. - 2003. - V.111. - P.986-990.

14. Fetal growth and postnatal growth failure in very-low-birthweight infants / K-A. Marks, B. Reichman, A. Lusky [et al.] // Acta Paediatr. - 2006. - V.95. - P.236-242.

15. Senterre T. Optimizing early nutritional support based on recent recommendations in VLBW infants and postnatal growth restriction

/ T. Senterre, J. Rigo // JPGN. - 2011. - V.53. - P.536-542.

16. A nutritional program to improve outcome of very low birth weight infants / N. Rochow, G. Fusch, A. Mühlinghaus [et al.] // Clin. Nutr. - 2012. - V.31. - P.124-131.

17. Growth in high risk infants $<1,500 \mathrm{~g}$ birthweight during the first 5 weeks / A. Loui, E. Tsalikaki, K. Maier [et al.] // Early Hum. Dev. - 2008. - V.84. - P.645-650.

18. Growth and nutrient intake among very-low-birth-weight infants fed fortified human milk during hospitalization / C. Henriksen, A.C. Westerberg, A. Ronnestad [et al.] // Br. J. Nutr. - 2009. - V.102. - P. 1179-1186.

19. Growth in the neonatal intensive care unit influences neurodevelopmental and growth outcomes of extremely low birth weight infants / R.A. Ehrenkranz, A.M. Dusick, B.R. Vohr [et al.] // Pediatrics. - 2006. - V.117. - P.1253-1261

20. Postnatal growth in VLBW infants: significant association with neurodevelopmental outcome / B. Latal-Hajnal, K. Siebenthal, H. Kovari [et al.] // J. Pediatr. - 2003. - V.143. - P.163-170.

21. Intrauterine, early neonatal and postdischarge growth and neurodevelopmental outcome at 5.4 years in extremely preterm infants after intensive neonatal nutritional support / A.R. Franz, F. Pohlandt, H. Bode [et al.] // Pediatrics. - 2009. - V.123. - P.e101-e109.

22. The Dutch POPS-19 Collaborative Study Group: Intelligence of very preterm or very low birthweight infants in young adulthood / N. Weisglas-Kuperus, E.T.M. Hille, H.J. Duivenvoorden [et al.] // Arch. Dis. Child Fetal Neonatal Ed. - 2009. - V.94. - P.F196-F200.

23. A clinical prediction model to stratify retinopathy of prematurity risk using postnatal weight gain / G. Binenbaum, G. Ying, G.E. Quinn [et al.] // Pediatrics. - 2011. - V.127. - P.e607-e614.

24. Lucas A. Randomised trial of early diet in preterm babies and later intelligence quotient / A. Lucas, R. Morley, T.J. Cole // BMJ. - 1998. - V.317. - P.1481-1487.

25. Preterm birth and body composition at term equivalent age: a systematic review and meta-analysis / M.J. Johnson, S.A. Wootton, A.A. Leaf [et al.] // Pediatrics 2012. - V.130. - P.e640-649.

26. Body composition changes in preterm infants following hospital discharge: comparison with term infants / S.E. Ramel, H.L. Gray, K.L. Ode [et al.] // JPGN. - 2011. - V.53. - P.333-338.

27. Postnatal malnutrition of extremely low birth-weight infants with catch-up growth postdischarge / K.D. Ernst, P.G. Radmacher, S.T. Rafail [et al.] // J. Perinatol. - 2003. - V.23. - P.477-482.

28. Early and aggressive nutritional strategy (parenteral and enteral) decreases postnatal growth failure in very low birth weight infants / A. Dinerstein, RM. Nieto, CL. Solana [et al.] // J. Perinatol.- 2006.-V.26(7).-P.436-42.

29. Infant growth before and after term: effects on neurodevelopment in preterm infants / M.B. Belfort, S.L. Rifas-Shiman, T. Sullivan

[et al.] // Pediatrics. - 2011. - V.128. - P.e899-906.

30. Fuglestad A.J. The role of nutrition in cognitive development / A.J. Fuglestad, R. Rao, M.K. Georgieff // Handbook of developmental cognitive neuroscience; eds. C.A. Nelson, L. Luciana. - [2nd ed.]. - Cambridge (United Kingdom): MIT Press, 2008. - P.623-642.

31. High-protein formulas. Evidence for use in preterm infants / L.D. Brown, K. Hendrickson, M.L. Masor [et al.] // Clin. Perinatol. - 2014. - V.41. - P. 383-403.

32. Fenton T.R. A systematic review and meta-analysis to revise the Fenton growth chart for preterm infants / T.R. Fenton, J.H. Kim // BMC Pediatrics. - 2013. - V.13. - P.59-72.

33. UK-WHO growth charts [Електронний ресурс]. - Режим доступу: http://www.rcpch.ac.uk/Research/ UK-WHO-Growth-Charts.

34. A new and improved population-based Canadian reference for birth weight for gestational age / M.S. Kramer, R.W. Platt, S.W. Wen

[et al.] // Pediatrics. - 2001. - V.108. - P.2/e35.

35. Body composition, nutrition, and fluid balance during the first two weeks of life in preterm neonates weighing less than $1,500 \mathrm{~g} /$

K. Bauer, G. Bovermannn, A. Roithmaier [et al.] // J. Pediatr. - 1991. - V.118. - P.615-620.

36. Embleton N.E. Postnatal malnutrition and growth retardation: an inevitable consequence of current recommendations in preterm infants? / N.E. Embleton, N. Pang, R.J. Cooke // Pediatrics. - 2001. -V.107. - P.270-273.

37. Cormack B.E. Audit of feeding practices in babies $<1,200 \mathrm{~g}$ or 30 weeks gestation during the first month of life / B.E. Cormack,

F.H. Bloomfield // J. Paediatr. Child Health. - 2006. - V.42. - P.458-463.

38. First-week protein and energy intakes are associated with 18 -month developmental outcomes in extremely low birth weight infants

/ B.E. Stephens, R.V. Walden, R.A. Gargus [et al.] // Pediatrics. - 2009. - V.123. - P.1337-1343.

39. Enteral nutrient supply for preterm infants: commentary from the European Society for Paediatric Gastroenterology, Hepatology, and Nutrition Committee on Nutrition / C. Agostoni, G. Buonocore, V.P. Carnielli [et al.] // JPGN. - 2010. - V.50. - P.85-91.

40. Adams-Chapman I. Neurodevelopmental outcome of the late preterm infant / I. Adams-Chapman // Clin. Perinatol. - 2006. - V.33. - P.947-964.

41. Aggressive early total parenteral nutrition in low-birth-weight infants / H.M. Ibrahim, M.A. Jeroudi, R.J. Baier [et al.] // J.

Perinatol. - 2004. - V.24. - P.482-486.

42. Amino acid administration to premature infants directly after birth / F.W.J. te Braake, C.H.P. van den Akker, D.J.L. Wattimena [et al.] // J. Pediatr. - 2005. - V.147. - P. 457-461.

43. Nutritional practices in the neonatal intensive care unit: analysis of a 2006 Neonatal Nutrition Survey / D.M. Hans, M. Pylipow,

J.D. Long [et al.] // Pediatrics. - 2009. - V.123. - P.51-57.

44. Berseth C.L. Effect of early feeding on maturation of the preterm infant's small intestine / C.L.Berseth // J. Pediatr. - 1992. V.120. - P.947-953.

45. Arslanoglu S. Adjustable fortification of human milk fed to preterm infants: does it make a difference? / S. Arslanoglu, G.E. Moro,

E.E. Ziegler // J. Perinatol. - 2006. - V.26. - P.614-621.

46. Target fortification of breast milk with fat, protein, and carbohydrates for preterm infants / N. Rochow, G. Fusch, A. Choi [et al.] 
// J. Pediatr. - 2013. - V.163. - P.1001-1007.

47. Carlson S.E. Feeding after discharge: growth, development, and long-term effects / S.E. Carlson // Nutrition of the preterm infant: scientific basis and practical guidelines, 2nd edition. - Eds. R.C. Tsang, R. Uauy, B. Koletzko [et al.]. - Cincinnati (OH): Digital Educational Publishing, Inc, 2005. - p. 357-382.

48. Cooke R.J. Adiposity is not altered in preterm infants fed with a nutrient-enriched formula after hospital discharge / R.J. Cooke, I.J. Griffin, K. McCormick // Pediatr. Res. - 2010. - V. 67. - P.660-664.

49. Benefits of supplemented preterm formulas on insulin sensitivity and body composition after discharge from the neonatal intensive care unit / E. Pittaluga, P.Vernal, A.Llanos [et al.] // J. Pediatr. - 2011. - V.159. - P.926-932.

50. Growth and bone mineralization in preterm infants fed preterm formula or standard term formula after discharge / J.C. Picaud, E. Decullier, O.Plan [et al.] // J. Pediatr. - 2008. - V.153. - P. 616-621.

51. Optimal growth and lower fat mass in preterm infants fed a protein-enriched postdischarge formula / E.M. Amesz, A. Schaafsma, A. Cranendonk [et al.] // J. Pediatr. Gastroenterol. Nutr. - 2010. - V.50. - P.200-207.

52. Interventional strategies to promote appropriate growth / E. Ziegler, S.J. Carlson, S. E. Nelson // Maternal and Child Nutrition: The First 1,000 Days. - Eds. J. Bhatia, Z.A. Bhutta, S.C. Kalhan. - Nestlé Nutr. Inst. Workshop Ser. - 2013. - V. 74. - P.181-192.

\section{СТРАТЕГИИ ПИТАНИЯ, ОБЕСПЕЧИВАЮЩИЕ ОПТИМАЛЬНОЕ ПОСТНАТАЛЬНОЕ ФИЗИЧЕСКОЕ РАЗВИТИЕ НЕДОНОШЕННЫХ МЛАДЕНЦЕВ}

\section{Д.А. Добрянський}

\author{
Львовский национальный медицинский \\ университет имени Данила Галицкого \\ (г. Львов, Украина)
}

Резюме. Здоровый рост и развитие ребенка в первые 1000 дней жизни имеет критическое значение не только для выживания и улучшения показателей здоровья в раннем детстве, но и для профилактики важных неинфекционных заболеваний старшего возраста. Оптимальное постнатальное физическое развитие недоношенных детей можно определить как такое, что не связано с неблагоприятными последствиями в краткосрочной и долгосрочной перспективе. В то же время, задержка развития достоверно коррелирует с неадекватным питанием и отдаленными негативными неврологическими последствиями. Итак, надлежащее питание должно обеспечивать достижение оптимальных показателей физического развития благодаря поддержке постоянного необходимого уровня потребления основных нутриентов и энергии. Полноценное парентеральное питание следует начинать сразу после рождения глубоко недоношенного ребенка и продолжать до момента полного установления энтерального питания. На фоне парентерального введения нутриентов так же от рождения нужно назначать минимальное энтеральное питание, которое стимулирует созревание незрелого желудочно-кишечного тракта преждевременно родившегося ребенка. Грудное молоко является лучшим продуктом минимального питания, поскольку оно является более эффективным и безопасным, чем альтернативные средства. В качестве источника питательных веществ, грудное молоко, однако, не обеспечивает повышенных потребностей глубоко недоношенного ребенка, что определяет необходимость его обогащения, а также использования других специальных продуктов питания в течение первого года жизни ребенка. Чтобы обеспечить оптимальные показатели постнатального физического развития глубоко недоношенных младенцев и соответственно улучшить их отдаленный неврологический прогноз, нужна комплексная стратегия питания и мониторинга развития в течение первых лет их жизни с участием неонатологов, педиатров и врачей семейной практики.

Ключевые слова: питание, постнатальное физическое развитие, преждевременно рожденные младенцы.

\section{STRATEGIES OF FEEDING WHICH ENSURE OPTIMIZED POSTNATAL DEVELOPMENT OF PRETERM INFANTS}

\section{D.O.Dobryansky}

\author{
Danila Halutsky national medical university \\ (Lviv, Ukraine)
}

Summary. Healthy growth and development during the first 1,000 days of a child's life are of critical value in relation not to only immediate survival and morbidity but to the prevention of many important noncommunicable disorders development later in life. Optimal growth of premature infants can be defined as growth that is not associated with any adverse consequences in the short and the long term. At the same time, growth failure is associated with inadequate nutrition and long-term neurocognitive impairment. Therefore, appropriate nutrition should maintain optimal growth by ensuring that nutrient intakes are maintained at all times at adequate levels. Parenteral administration of nutrients must begin immediately at birth of very preterm infant and needs to be continued until enteral nutrition is fully established. While nutritional support is provided by parenteral nutrition, minimal enteral nutrition, also beginning at birth, stimulates the immature gastrointestinal tract to undergo maturation. Human milk is the preferred product for minimal nutrition because it is more effective and safer than alternative agents. As a source of nutrients, however, human milk is incomplete for the very preterm infant that determines the need for its fortification or for use the other special nutrition products. To ensure optimal postnatal growth of very preterm infants and accordingly to improve their long term neurological prognosis, a comprehensive strategy of nutrition and monitoring during the first years of life is needed with participation of neonatologists, pediatricians and family practice physicians.

Keywords: nutrition, postnatal growth, preterm infants. 